\title{
Teachers' sense of efficacy and technology acceptance during the COVID-19 pandemic
}

\author{
Katherine Carl, Governors State University, kcarl@govst.edu
}

\begin{abstract}
The COVID-19 pandemic has greatly impacted the way in which learners learn and educators deliver classroom instruction. K-12 teachers in the United States that previously taught solely in face-to-face settings have been forced to adopt technology to support remote and hybrid teaching. This study investigates the impact of remote and hybrid teaching environments on teachers' sense of efficacy (TSES) and measures of the technology acceptance model (TAM). Repeated measures analysis revealed significant differences in measures of both teachers' sense of efficacy and technology acceptance in faceto-face, remote, and hybrid teaching modalities. Based on results, we discuss implications for K-12 classroom teaching and suggest further research related to TSES and TAM.
\end{abstract}

Keywords: teachers' sense of efficacy, technology acceptance model, covid-19, remote learning, hybrid learning

\section{Introduction}

The COVID-19 pandemic has affected many aspects of life, as safety regulations designed to limit transmission of the disease have led to a vast increase in remote rather than face-to-face interaction. In education, this shift in paradigm thrust the responsibility of remote learning onto teachers that may not have been prepared to use technology required for online instruction. For many educators and support staff, inexperience using online tools on a daily basis and insufficient technological and pedagogical support made remote learning especially challenging (Shamir-Inbal \& Blau, 2021). As COVID-19 restrictions lifted in the United States, many K-12 school districts implemented hybrid instruction in which teachers and some learners returned to the classroom, while others remained at home using remote learning technology. The hybrid approach was desirable to many parents, educators, and medical professionals, as research demonstrated the important educational, social, and developmental benefits of in-person learning for children (Levinson \& Lipsitch, 2020). As education continues to require the use of technology that enables remote and/or hybrid instruction, it is imperative that school administrators and teachers understand the effects of adoption so that strategic decisions related to remote education can be made that benefit learners.

The aim of this study is to evaluate differences in teachers' sense of efficacy and technology acceptance in face-to-face, remote, and hybrid settings with the goal of providing administrators and educators feedback related to changes in instructional modality. We first review literature related to teachers' sense of efficacy (TSES) and the technology acceptance model (TAM) and discuss the theoretical background of each. We then describe our research methodology, present and discuss implications of our results, and finally offer suggestions for future research. 


\section{Issues in Information Systems}

Volume 22, Issue 4, pp. 59-68, 2021

\section{Literature Review}

Prior to and throughout the COVID-19 pandemic, teachers' sense of efficacy and technology acceptance have been explored in remote and hybrid instructional contexts. Teachers' sense of efficacy in classroom management, student engagement, and instructional strategies has been investigated with the aim of improving self-efficacy in those areas. Teachers with previous online teaching experience, including using learning management systems (LMS) and technology, demonstrated higher self-efficacy than those with limited experience (Dolighan \& Owen, 2021). Similarly, teachers' perception of ease of use and usefulness have been found to be predictors of technology acceptance in both remote and hybrid settings (Rasheed, Kamsin, \& Abdullah, 2020).

A study applying the Teaching Self-Efficacy Scale (TESS) and technology acceptance model (TAM) demonstrated that levels of perceived usefulness and system quality predict teachers' motivational selfefficacy in remote teaching and that levels of perceived usefulness, system quality, and facilitating conditions can significantly predict levels of instructional self-efficacy (Cardullo, Wang, Burton, \& Dong, 2021). A meta-analysis of hybrid instruction summarized the pedagogical challenges from the teacher's perspective as that of a radical shift in method to accommodate new technology (Raes, Detienne, Windey, \& Depaepe, 2020). Our aim is to explore the differences between measures of TSES and TAM in face-toface, remote, and hybrid settings.

\section{Theoretical Background}

\section{Teachers' Sense of Efficacy}

Teachers' sense of efficacy (TSES) was created by Tschannen-Moran and Woolfolk Hoy as a method of measuring teachers' judgment in competence in three areas in the classroom including classroom management, student engagement, and instructional strategies (Tschannen-Moran \& Woolfolk Hoy, 2001). The instrument's theoretical underpinnings lie in Bandura's work in general self-efficacy (Bandura, 1982). Self-efficacy in the three areas measured by the model has been shown to result in higher enthusiasm for teaching, a less critical attitude towards learner mistakes, and higher teacher retention (Ebmeier, 2003; Woolfolk Hoy, 2008). Items from the measurement model are shown in detail in Table 3.

\section{Technology Acceptance Model}

The Technology Acceptance Model (TAM) was created and revised by Davis based on the psychological theory of reasoned action, which posits that an individual's behaviour is driven by behavioural intention as a function of attitude towards behaviour and norms surrounding performance of the behaviour (TRA) (Davis, 1989; Venkatesh \& Davis, 2000). The original model is shown in Figure 1. TAM has been applied in many contexts and disciplines, including information systems, education, and health services (Hsu \& Ya-Hui, 2017; Mezhuyev, Al-Emran, Ismail, Benedicenti, \& Chandran, 2019; Min, Xu, \& Yu, 2004). A meta-analysis demonstrated the strong viability of TAM as a model for technology acceptance in the field of education (Scherer, Siddiq, \& Tondeur, 2019). 


\section{Issues in Information Systems}

Volume 22, Issue 4, pp. 59-68, 2021

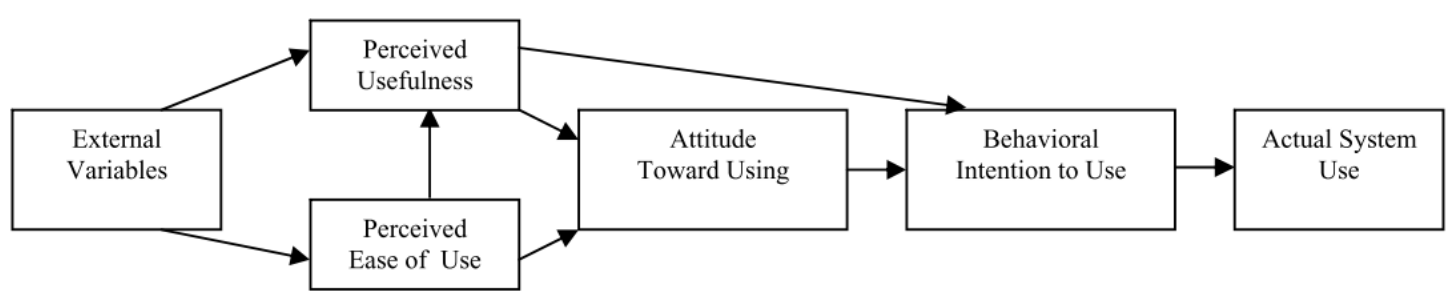

Figure 1. Technology Acceptance Model

\section{Face-to-Face vs. Remote vs. Hybrid Instruction}

In this study, we are interested in the differences among face-to-face, remote, and hybrid instruction. With respect to measures of teachers' sense of efficacy, we expect responses in classroom management, instructional strategies, and student engagement to be higher in modalities that allow for more reliable interaction with learners.

Table 1. Research Hypotheses

\begin{tabular}{|c|c|}
\hline Hypothesis & Relationship Tested \\
\hline $\mathrm{H} 1 \mathrm{a}, \mathrm{b}$ & $\begin{array}{l}\text { Teachers' sense of efficacy in classroom management is greater in a face-to-face } \\
\text { setting than in a remote or hybrid setting. }\end{array}$ \\
\hline $\mathrm{H} 1 \mathrm{c}$ & $\begin{array}{l}\text { Teachers' sense of efficacy in classroom management is greater in a hybrid setting } \\
\text { than in a remote setting. }\end{array}$ \\
\hline $\mathrm{H} 2 \mathrm{a}, \mathrm{b}$ & $\begin{array}{l}\text { Teachers' sense of efficacy in student engagement is greater in a face-to-face setting } \\
\text { than in a remote or hybrid setting. }\end{array}$ \\
\hline $\mathrm{H} 2 \mathrm{c}$ & $\begin{array}{l}\text { Teachers' sense of efficacy in student engagement is greater in a hybrid setting than } \\
\text { in a remote setting. }\end{array}$ \\
\hline $\mathrm{H} 3 \mathrm{a}, \mathrm{b}$ & $\begin{array}{l}\text { Teachers' sense of efficacy in instructional strategies is greater in a face-to-face } \\
\text { setting than in a remote or hybrid setting. }\end{array}$ \\
\hline $\mathrm{H} 3 \mathrm{c}$ & $\begin{array}{l}\text { Teachers' sense of efficacy in instructional strategies is greater in a hybrid setting } \\
\text { than in a remote setting. }\end{array}$ \\
\hline $\mathrm{H} 4$ & $\begin{array}{l}\text { Teachers' perceived usefulness of their instructional tool is greater in a remote } \\
\text { setting than in a hybrid setting. }\end{array}$ \\
\hline H5 & $\begin{array}{l}\text { Teachers' perceived ease of use of their instructional tool is greater in a remote } \\
\text { setting than in a hybrid setting. }\end{array}$ \\
\hline H6 & $\begin{array}{l}\text { Teachers' attitude towards use of their instructional tool is greater in a remote setting } \\
\text { than in a hybrid setting. }\end{array}$ \\
\hline H7 & $\begin{array}{l}\text { Teachers' intent to use their instructional tool is greater in a remote setting than in a } \\
\text { hybrid setting. }\end{array}$ \\
\hline
\end{tabular}

With respect to the technology acceptance model, the nuances of technology use in each modality must be considered. The use of technology varies across these modalities, as in face-to-face instruction technology is not necessarily considered to be required to accomplish teaching and learning goals. In the remote setting, technology is necessary to enable interaction among teacher, learner, and content. The hybrid setting also requires technology to communicate with learners not present in the classroom but is not necessarily required to interact with in-person learners. Our hypotheses related to measures of TSES and TAM in each instructional modality are shown in Table 1.

We expect measures of teachers' sense of efficacy to be greatest in the face-to-face setting and higher in the hybrid setting than in the remote setting $(\mathrm{H} 1-\mathrm{H} 3)$. We also expect the measures of perceived usefulness, perceived ease of use, attitude towards use, and intent to use technology to be greater in the 


\section{Issues in Information Systems}

Volume 22, Issue 4, pp. 59-68, 2021

remote than the hybrid setting, as technology is required in the remote setting to accomplish teaching and learning goals $(\mathrm{H} 4-\mathrm{H} 7)$.

\section{Methodology}

Responses to an online questionnaire were collected from K-12 teachers and support staff in a large school district in the midwestern United States. Participants were contacted via email over a period of four months. A total of 45 complete responses was collected from teachers and support staff with experience serving learners in face-to-face and remote classrooms. Thirty-three of the total participants also contributed responses to items related to teaching in a hybrid classroom. Details of face-to-face, remote, and hybrid instructional modalities are provided in Table 2. Participants were selected because they experienced faceto-face instruction prior to the COVID-19 pandemic, transitioned to remote instruction during the COVID19 pandemic, and eventually were required to use a hybrid model of instruction.

Table 2. Descriptions of Instructional Modalities

\begin{tabular}{|l|l|}
\hline Instructional Modality & Description \\
\hline Face-to-face & $\begin{array}{l}\text { Respondent and learners participated in classroom activities while } \\
\text { physically co-located in a classroom. }\end{array}$ \\
\hline Remote & $\begin{array}{l}\text { Respondent and learners participated in classroom activities virtually } \\
\text { using an online communication tool. }\end{array}$ \\
\hline Hybrid & $\begin{array}{l}\text { Respondent and learners whose guardian(s) granted permission to be } \\
\text { physically present in a school classroom participated in classroom } \\
\text { activities while physically co-located and equipped with an online } \\
\text { communication tool. Learners whose guardian(s) did not grant } \\
\text { permission to be physically present participated in classroom activities } \\
\text { virtually using an online communication tool. }\end{array}$ \\
\hline
\end{tabular}

\section{Participants}

The participants ranged in age from 23 to 61 with a mean age of 40.8 and median age of 42 . There were six male and 39 female participants that taught between grades one and twelve. Participants included science, math, English language arts, music, art, and foreign language teachers, as well as support staff.

\section{Questionnaire}

Participants provided demographic information and then responded to survey items used to measure factors related to teachers' sense of efficacy and technology acceptance (Davis, 1989; Masrom, 2007; TschannenMoran \& Woolfolk Hoy, 2001). Participants responded to items related to the TSES model while considering face-to-face, remote, and hybrid instruction. Items used to measure efficacy in student engagement, instructional strategies, and classroom management are shown in Table 3.

A 5-point Likert scale was used to measure each item $(1=$ None at All, $2=$ Very Little, $3=$ Some Degree, $4=$ Quite a Bit, $5=$ A Great Deal).

Participants also responded to items measuring factors from TAM while considering the tool they used most to deliver remote and hybrid classroom instruction. Items used to measure perceived usefulness, perceived ease of use, attitude towards use, and intent to use are shown in Table 4. A 5-point Likert scale was used to measure each item $(1=$ Strongly Disagree, $2=$ Disagree, $3=$ Neither Agree nor Disagree, $4=$ Agree, 5 = Strongly Agree) . 


\section{Issues in Information Systems}

Volume 22, Issue 4, pp. 59-68, 2021

Table 3. Research Instrument: Teachers' Sense of Efficacy

\begin{tabular}{|c|c|c|}
\hline Model & Variables & Items \\
\hline \multirow{12}{*}{$\begin{array}{l}\text { Teachers' } \\
\text { Sense of } \\
\text { Efficacy }\end{array}$} & \multirow{4}{*}{$\begin{array}{l}\text { Efficacy in } \\
\text { Student } \\
\text { engagement }\end{array}$} & $\begin{array}{l}\text { How much can you do to motivate learners who show low interest in } \\
\text { school work? }\end{array}$ \\
\hline & & How much can you do to help your learners value learning? \\
\hline & & $\begin{array}{l}\text { How much can you do to get learners to believe they can do well in school } \\
\text { work? }\end{array}$ \\
\hline & & $\begin{array}{l}\text { How much can you assist families in helping their children do well in } \\
\text { school? }\end{array}$ \\
\hline & \multirow{4}{*}{$\begin{array}{l}\text { Efficacy in } \\
\text { Instructional } \\
\text { Strategies }\end{array}$} & To what extent can you craft good questions for your learners? \\
\hline & & To what extent can you use a variety of assessment strategies? \\
\hline & & $\begin{array}{l}\text { To what extent can you provide an alternative explanation or example } \\
\text { when learners are confused? }\end{array}$ \\
\hline & & $\begin{array}{l}\text { How well can you implement alternative teaching strategies in your } \\
\text { classroom? }\end{array}$ \\
\hline & \multirow{4}{*}{$\begin{array}{l}\text { Efficacy in } \\
\text { Classroom } \\
\text { Management }\end{array}$} & How much can you do to control disruptive behaviour in the classroom? \\
\hline & & How much can you do to calm a learner who is disruptive or noisy? \\
\hline & & How much can you do to get children to follow classroom rules? \\
\hline & & $\begin{array}{l}\text { How well can you establish a classroom management system with each } \\
\text { group of learners? }\end{array}$ \\
\hline
\end{tabular}

Table 4. Research Instrument: Technology Acceptance Model

\begin{tabular}{|c|c|c|}
\hline Model & Variables & Items \\
\hline \multirow{17}{*}{$\begin{array}{l}\text { Technology } \\
\text { Acceptance }\end{array}$} & \multirow{6}{*}{$\begin{array}{l}\text { Perceived } \\
\text { Usefulness }\end{array}$} & ...promotes the achievement of class learning objectives. \\
\hline & & ...enables learner-content interaction. \\
\hline & & ...enables active learning. \\
\hline & & ...enables learner-instructor interaction. \\
\hline & & ...enables learner-learner interaction. \\
\hline & & ...enables formative assessment. \\
\hline & \multirow{5}{*}{$\begin{array}{l}\text { Perceived } \\
\text { Ease of Use }\end{array}$} & ...has been an easy tool for me to learn. \\
\hline & & ...has been an easy tool for me to teach or otherwise serve with. \\
\hline & & ...is clear and understandable. \\
\hline & & ...is flexible to interact with. \\
\hline & & ...would be easy for me to master. \\
\hline & \multirow[t]{3}{*}{$\begin{array}{l}\text { Attitude } \\
\text { Towards Use }\end{array}$} & $\begin{array}{l}\text {..w was the best choice for content delivery during the COVID-19 } \\
\text { pandemic. }\end{array}$ \\
\hline & & $\begin{array}{l}\text {...is compatible with the hardware devices I use during the COVID-19 } \\
\text { pandemic. }\end{array}$ \\
\hline & & $\begin{array}{l}\text {...is a tool I would like to use to meet teaching objectives after the } \\
\text { COVID-19 pandemic is over. }\end{array}$ \\
\hline & \multirow[t]{3}{*}{ Intent to Use } & $\begin{array}{l}\text {...is a tool I will definitely use to meet teaching objectives after the } \\
\text { COVID-19 pandemic is over. }\end{array}$ \\
\hline & & $\begin{array}{l}\text {...is a tool I recommend to meet teaching objectives after the COVID-19 } \\
\text { pandemic is over. }\end{array}$ \\
\hline & & $\begin{array}{l}\text {...is a tool I will definitely use to meet teaching objectives after the } \\
\text { COVID-19 pandemic is over. }\end{array}$ \\
\hline
\end{tabular}




\section{Issues in Information Systems}

Volume 22, Issue 4, pp. 59-68, 2021

\section{Results}

Participants reported teachers' sense of efficacy in face-to-face, remote, and hybrid modalities and technology acceptance in remote and hybrid modalities. Repeated measures analysis was conducted using SPSS across modalities to assess differences among measures of each model (Field, 2017).

\section{Teachers' Sense of Efficacy: Face-to-Face, Remote, and Hybrid Modalities}

Repeated measures analysis of variance (ANOVA) was performed on instructional modality at three levels (face-to-face, remote, and hybrid) on the measures of teachers' sense of efficacy in classroom management, student engagement, and instructional strategies. Mauchly's test indicated that the assumption of sphericity had not been violated for modality on the measures of classroom management $\left[\chi^{2}(2)=2.584, p=0.275\right]$, student engagement $\left[\chi^{2}(2)=5.250, p=0.072\right]$, or instructional strategies $\left[\chi^{2}(2)=2.608, p=0.271\right]$.

All effects are reported as significant at $p<0.05$. There was a significant main effect of the type of instructional modality (sphericity assumed) on the measures of teachers' sense of efficacy in classroom management $[\mathrm{F}(2,66)=19.411]$, student engagement $[\mathrm{F}(2,66)=23.232]$, and instructional strategies $[\mathrm{F}(2$, $66)=17.644]$. The mean and standard deviation of each measure across each modality is shown in Table 5.

Table 5. Teachers' Sense of Efficacy Means

\begin{tabular}{|l|l|r|r|}
\hline Measure & Modality & Mean & Std. Deviation \\
\hline Classroom management & Face-to-face & 4.32 & 0.66 \\
\hline & Remote & 3.36 & 0.93 \\
\hline & Hybrid & 3.74 & 0.83 \\
\hline Student engagement & Face-to-face & 3.88 & 0.56 \\
\hline & Remote & 3.01 & 0.80 \\
\hline & Hybrid & 3.40 & 0.64 \\
\hline Instructional Strategies & Face-to-face & 4.31 & 0.56 \\
\hline & Remote & 3.51 & 0.89 \\
\hline & Hybrid & 3.59 & 0.96 \\
\hline
\end{tabular}

Table 6. Teachers' Sense of Efficacy Results

\begin{tabular}{|l|l|l|}
\hline Hypothesis & Relationship Tested & Results \\
\hline H1a, b & $\begin{array}{l}\text { Teachers' sense of efficacy in classroom management is greater in } \\
\text { a face-to-face setting than in a remote or hybrid setting. }\end{array}$ & Supported $(\mathrm{p}<0.001)$ \\
\hline H1c & $\begin{array}{l}\text { Teachers' sense of efficacy in classroom management is greater in } \\
\text { a hybrid setting than in a remote setting. }\end{array}$ & Supported $(\mathrm{p}<0.008)$ \\
\hline H2a, b & $\begin{array}{l}\text { Teachers' sense of efficacy in student engagement is greater in a } \\
\text { face-to-face setting than in a remote or hybrid setting. }\end{array}$ & Supported $(\mathrm{p}<0.001)$ \\
\hline H2c & $\begin{array}{l}\text { Teachers' sense of efficacy in student engagement is greater in a } \\
\text { hybrid setting than in a remote setting. }\end{array}$ & Supported $(\mathrm{p}=0.001)$ \\
\hline H3a, b & $\begin{array}{l}\text { Teachers' sense of efficacy in instructional strategies is greater in } \\
\text { a face-to-face setting than in a remote or hybrid setting. }\end{array}$ & Supported $(\mathrm{p}<0.001)$ \\
\hline H3c & $\begin{array}{l}\text { Teachers' sense of efficacy in instructional strategies is greater in } \\
\text { a hybrid setting than in a remote setting. }\end{array}$ & Not supported $(\mathrm{p}=0.531)$ \\
\hline
\end{tabular}




\section{Issues in Information Systems}

Volume 22, Issue 4, pp. 59-68, 2021

Pairwise comparisons revealed that there are significant differences between measures of teachers' sense of efficacy in classroom management and student engagement in face-to-face and remote instruction, faceto-face and hybrid instruction, and remote and hybrid instruction modalities. However, there is no significant difference between measures of teachers' sense of efficacy in instructional strategies in remote and hybrid instruction modalities. Results as applied to our hypotheses are shown in Table 6.

\section{Technology Acceptance: Remote and Hybrid Modalities}

Repeated measures analysis of variance (ANOVA) was performed on instructional modality at two levels (remote and hybrid) on the measures of the technology acceptance model in perceived usefulness, perceived ease of use, attitude towards use, and intent to use.

Table 7. Technology Acceptance Means

\begin{tabular}{|l|l|r|r|}
\hline Measure & Modality & Mean & Std. Deviation \\
\hline Perceived usefulness & Remote & 3.43 & 0.74 \\
\hline & Hybrid & 3.51 & 0.80 \\
\hline Ease of use & Remote & 3.83 & 0.94 \\
\hline & Hybrid & 3.38 & 1.10 \\
\hline Attitude towards use & Remote & 4.24 & 0.62 \\
\hline & Hybrid & 3.88 & 0.88 \\
\hline Intent to use & Remote & 3.07 & 1.17 \\
\hline & Hybrid & 2.82 & 1.29 \\
\hline
\end{tabular}

Sphericity is assumed with only two levels of modality. All effects are reported as significant at $\mathrm{p}<0.05$. There was a significant main effect of the type of instructional modality on the measures of technology acceptance in perceived ease of use $[\mathrm{F}(1,33)=7.920]$ and attitude towards use $[\mathrm{F}(1,33)=5.669]$. There was no significant main effect on perceived usefulness $[\mathrm{F}(1,33)=0.718]$ or intent to use $[\mathrm{F}(1,33)=1.449]$. The mean and standard deviation of each measure across each modality is shown in Table 7. Results as applied to our hypotheses are shown in Table 8 .

Table 8. Technology Acceptance Model Results

\begin{tabular}{|l|l|l|}
\hline Hypothesis & Relationship Tested & Results \\
\hline H4 & $\begin{array}{l}\text { Teachers' perceived usefulness of their instructional tool is } \\
\text { greater in a remote setting than in a hybrid setting. }\end{array}$ & Not supported $(\mathrm{p}=0.403)$ \\
\hline H5 & $\begin{array}{l}\text { Teachers' perceived ease of use of their instructional tool } \\
\text { is greater in a remote setting than in a hybrid setting. }\end{array}$ & Supported $(\mathrm{p}=0.008)$ \\
\hline H6 & $\begin{array}{l}\text { Teachers' attitude towards use of their instructional tool is } \\
\text { greater in a remote setting than in a hybrid setting. }\end{array}$ & Supported $(\mathrm{p}=0.023)$ \\
\hline H7 & $\begin{array}{l}\text { Teachers' intent to use their instructional tool is greater in } \\
\text { a remote setting than in a hybrid setting. }\end{array}$ & Not supported $(\mathrm{p}=0.237)$ \\
\hline
\end{tabular}




\section{Issues in Information Systems}

Volume 22, Issue 4, pp. 59-68, 2021

\section{Discussion}

With respect to teachers' sense of efficacy, we confirmed that self-efficacy in classroom management, student engagement, and instructional strategies is highest in the face-to-face setting. We also confirmed that self-efficacy in classroom management and student engagement is higher in the hybrid setting than the remote setting, as teachers are more confident in their ability to maintain classroom order and engagement when some learners are present in the classroom. However, we did not see a difference in self-efficacy in instructional strategies in remote and hybrid settings. This result suggests that from the teacher's perspective, remote and hybrid instruction are quite similar. Teachers with learners at home, regardless of the presence of learners in the classroom, require technology to achieve learning outcomes.

The lack of difference in remote and hybrid instruction with respect to self-efficacy in instructional strategies and perceived usefulness is likely a function of the logistics of the two modalities being almost identical. Despite being present in the classroom with some learners, teachers are bound by the constraints of the technology required to interact with remote learners. If hybrid learning continues to be a popular choice in K-12 schools, considerations must be made for teachers to accommodate the similarity of the two instructional modalities. One consideration is the use of specially equipped hybrid classroom technology that engages face-to-face and remote learners simultaneously (Xu, Yang, \& MacLeod, 2018).

With respect to the technology acceptance model, we confirmed that teachers' perceived ease of use and attitude towards use of instructional technology is higher in the remote than the hybrid setting. Because the hybrid setting requires management of learners both in the classroom and at home, it is easier for teachers to use technology when it is the only method of interaction. Similarly, teachers' attitude towards use of technology to accomplish instructional goals is higher when it is absolutely necessary. However, we did not see a difference in perceived usefulness or intent to use technology between instructional settings. This suggests that teachers find technology as useful in the classroom when remote learners are also present as they do when all learners are remote. It is likely that we found no difference in intent to use technology as teachers are guided by the policies put in place by school administration.

Our findings suggest that when presented with both face-to-face and remote learners in a hybrid setting, teachers perceive technology as more difficult to use than in a remote only setting and that they are no less confident with their instructional strategies than in a remote only setting. This implies that when forced to engage with some (not all) learners via technology that teachers default to their perceptions of the remote setting rather than engaging uniquely with hybrid delivery. Unless the hybrid setting can be redesigned to allow teachers to engage with learners using methods distinct from the remote setting, these perceptions may not change. Furthermore, an opportunity may be missed to develop new methods to engage learners that may not be able to physically attend school. The nuances of the hybrid teaching modality are not yet fully understood and warrant further investigation, especially if health risks dictate that some learners continue to remain at home.

\section{Limitations and Future Work}

This study is limited to a small sample of teachers in one school district in the United States that used both remote and hybrid instructional techniques during the COVID-19 pandemic. Further exploration of remote and hybrid instruction with a larger sample size is warranted. Additionally, while indicators of TAM measures were adapted to suit remote and hybrid instruction teaching models based on previous research, further investigation into the validity of the items used may be beneficial (Masrom, 2007).

Potential relationships among measures from teachers' sense of efficacy and the technology acceptance 


\section{Issues in Information Systems}

Volume 22, Issue 4, pp. 59-68, 2021

model should continue to be investigated. It is our intention to explore those relationships by building on previous research through structural equation modelling (Alharbi \& Drew, 2019; Joo, Park, \& Lim, 2018). Additionally, a qualitative approach may be warranted to better understand the implications of the hybrid instructional modality.

\section{Conclusion}

In this study, we investigated differences in measures of teachers' sense of efficacy and technology acceptance in face-to-face, remote, and hybrid settings. Our results confirmed that teachers' sense of efficacy with respect to classroom management, student engagement, and instructional strategies is highest in the face-to-face setting, but also surprised us by suggesting that self-efficacy in instructional strategies is no different in the hybrid and remote modalities. Additionally, we found that teachers' attitude toward the use of technology and its perceived ease of use were higher in the remote than the hybrid setting, suggesting that the technology used is more suitable when all learners are remote. Our findings call for a more thorough investigation of the hybrid setting, especially as it is unclear whether or not all learners will ever return to a face-to-face setting. The nature of education continues to change, and the technology used to support it must continue to evolve as well.

\section{References}

Alharbi, S., \& Drew, S. (2019). The role of self-efficacy in technology acceptance. In Advances in Intelligent Systems and Computing (Vol. 880). https://doi.org/10.1007/978-3-030-02686-8_85

Bandura, A. (1982). Self-efficacy mechanism in human agency. American Psychologist, 37(2). https://doi.org/10.1037/0003-066X.37.2.122

Cardullo, V., Wang, C., Burton, M., \& Dong, J. (2021). K-12 teachers' remote teaching self-efficacy during the pandemic. Journal of Research in Innovative Teaching and Learning, 14(1), 32-45.

Davis, F. D. (1989). Perceived usefulness, perceived ease of use, and user acceptance of information technology. MIS Quarterly: Management Information Systems, 13(3). https://doi.org/10.2307/249008

Dolighan, T., \& Owen, M. (2021). Teacher efficacy for online teaching during the COVID-19 pandemic. Brock Education Journal, 30(1), 95. https://doi.org/10.26522/brocked.v30i1.851

Ebmeier, H. (2003). How supervision influences teacher efficacy and commitment: An investigation of a path model. Journal of Curriculum and Supervision, 18(2), 110-141.

Field, A. (2017). Discovering Statistics Using IBM SPSS Statistics. London, UK: SAGE.

Hsu, H.-H., \& Ya-Hui, W. (2017). Investigation of the effects of a nursing information system by using the technology acceptance model. Computers, Informatics, Nursing, 35(6), 315-322.

Joo, Y. J., Park, S., \& Lim, E. (2018). Factors influencing preservice teachers' intention to use technology: TPACK, teacher self-efficacy, and Technology Acceptance Model. Educational Technology and Society, 21(3), 48-59.

Levinson, M., \& Lipsitch, M. (2020). Reopening primary schools during the pandemic. The New England 


\section{Issues in Information Systems}

Volume 22, Issue 4, pp. 59-68, 2021

Journal of Medicine, 383, 981-985.

Masrom, M. (2007). Technology Acceptance Model and E-learning. In 12th International Conference on Education (pp. 21-24).

Mezhuyev, V., Al-Emran, M., Ismail, M. A., Benedicenti, L., \& Chandran, D. A. P. (2019). The Acceptance of Search-Based Software Engineering Techniques: An Empirical Evaluation Using the Technology Acceptance Model. IEEE Access, 7, 101073-101085. https://doi.org/10.1109/ACCESS.2019.2917913

Min, G., Xu, Y., \& Yu, Y. (2004). An Enhanced Technology Acceptance Model for Web-Based Learning. Journal of Information Systems Education, 15(4).

Raes, A., Detienne, L., Windey, I., \& Depaepe, F. (2020). A systematic literature review on synchronous hybrid learning: gaps identified. Learning Environments Research, 23(3), 269-290. https://doi.org/10.1007/s10984-019-09303-Z

Rasheed, R. A., Kamsin, A., \& Abdullah, N. A. (2020). Challenges in the online component of blended learning: A systematic review. Computers and Education, 144(March 2019), 103701. https://doi.org/10.1016/j.compedu.2019.103701

Scherer, R., Siddiq, F., \& Tondeur, J. (2019). The technology acceptance model (TAM): A meta-analytic structural equation modeling approach to explaining teachers' adoption of digital technology in education. Computers and Education, 128(0317), 13-35. https://doi.org/10.1016/j.compedu.2018.09.009

Shamir-Inbal, T., \& Blau, I. (2021). Facilitating Emergency Remote K-12 Teaching in ComputingEnhanced Virtual Learning Environments During COVID-19 Pandemic - Blessing or Curse? Journal of Educational Computing Research, 1-29. https://doi.org/10.1177/0735633121992781

Tschannen-Moran, M., \& Woolfolk Hoy, A. (2001). Teacher efficacy: capturing an elusive construct. Teaching and Teacher Education, 17, 783-805.

Venkatesh, V., \& Davis, F. D. (2000). A theoretical extention of the technology acceptance model: four longitudinal field studies. Management Science, 46(2), 186-204.

Woolfolk Hoy, A. (2008). Educational psychology: Active learning edition. Boston, MA: Allyn and Bacon.

Xu, J., Yang, H. H., \& MacLeod, J. (2018). STEP on connected classroom climate in a hybrid learning environment. International Journal of Innovation and Learning, 23(4). 